\title{
CTSD wt Allele
}

National Cancer Institute

\section{Source}

National Cancer Institute. CTSD wt Allele. NCI Thesaurus. Code C49706.

Human CTSD wild-type allele is located in the vicinity of 11 p15.5 and is approximately 11 $\mathrm{kb}$ in length. This allele, which encodes cathepsin D protein, plays a role in the degradation of intracellular proteins. Dysfunction of the CTSD gene is associated with malignant neoplasms of the breast. 